\title{
Research on influencing factors and effect of entrepreneurship policy of Chinese college students-- Empirical analysis based on S province
}

\author{
Weidong $\mathrm{Xi}^{1, \mathrm{a}}$, $\mathrm{Li} \mathrm{He}{ }^{2, \mathrm{~b}}$ \\ ${ }^{1}$ Dalian university of science and technology, School of economics and management, Dalian, Liaoning province \\ ${ }^{2}$ Dalian university of finance and economics, Higher vocational college, Dalian, Liaoning province
}

\begin{abstract}
In order to promote college graduates to start their own businesses, S provincial government has implemented a series of employment promotion and entrepreneurship guidance plans, set up "college students' entrepreneurship fund" and college students' entrepreneurship projects, and provided preferential policies such as tax exemption and exemption and entrepreneurship subsidies. However, these policies have not played the expected effect in promoting college graduates to start their own businesses, and they still need to be further improved in terms of the publicity of the policies, the pertinence of the objects supported, and the supporting services for starting their own businesses. This paper from the government, universities, enterprises, society, graduates and other main body of analysis, from multiple perspectives to improve the university students support policy countermeasures.
\end{abstract}

\section{Introduction}

The entrepreneurship rate of Chinese college graduates reached 2.9 percent in 2017 , and will continue to rise in the context of mass innovation and entrepreneurship. However, the entrepreneurship rate of college graduates in $\mathrm{S}$ province is less than $2 \%$, significantly lower than the national average. The low willingness of college graduates in $\mathrm{S}$ province to start their own businesses and the low success rate of starting their own businesses are generally related to many factors, such as the entrepreneurs themselves, S provincial government, universities and society. It is of great theoretical and practical significance to study the influencing factors of self-employment of college graduates in $\mathrm{S}$ province. At the same time, the research on the supportive policies for college graduates to start their own businesses in $\mathrm{S}$ province is helpful to deepen the understanding of the supportive policies for college graduates to start their own businesses, which is of great practical significance for $\mathrm{S}$ province to solve the problem of college graduates to start their own businesses, improve the current policies and even promote economic development.

\section{Analysis of factors influencing college graduates' self-employment in $S$ province}

The factors influencing college graduates' willingness to start their own businesses can be summarized as individual factors, family factors and social factors. Individual factors include gender, whether it is the only child, registered permanent residence, whether it is the source of students in the province, the type of school, major, entrepreneurial environment awareness, entrepreneurial mentality, etc. Family factors include parents' education level, parents' occupation, family income, etc. Social factors include employment pressure, entrepreneurship policy publicity, public opinion orientation, university entrepreneurship policy guidance, etc. This paper conducted a questionnaire survey on 200 graduates from 5 universities in $\mathrm{S}$ province, with a recovery rate of $100 \%$ and 200 valid questionnaires.

\subsection{Basic information of questionnaire survey}

This paper conducted a questionnaire survey on 200 graduates from 5 universities in $\mathrm{S}$ province, with a recovery rate of $100 \%$ and 200 valid questionnaires. The basic information of the respondents is shown in Table 1. From the perspective of gender, the gender ratio of male to female is reasonably distributed, with male accounts for $52 \%$ and female accounts for $48 \%$. The distribution of age is mainly under 23 . Only children account for a larger proportion, at $58 \%$. Urban registered permanent residence accounts for $60 \%$, students in the province account for $72 \%$, students in ordinary colleges and universities account for $58 \%$, major accounting for the largest proportion is economics and management major accounting for $38 \%$, followed by science and technology major accounting for $22 \%$.

e-maila93307717@qq.com; b245322436@qq.com 


\subsection{Investigation on influencing factors of college graduates' entrepreneurship in $S$ province}

Among the 200 respondents, 23 chose to start their own businesses, accounting for $11.5 \%$ of the total. It can be seen that under the background of national entrepreneurship initiative, college graduates have high enthusiasm and strong willingness to start their own businesses. As shown in Figure 1,

TABLE I. BASIC INFORMATION OF THE SAMPLE

\begin{tabular}{|c|c|c|c|c|c|c|c|}
\hline \multicolumn{2}{|c|}{ Characteristics of the } & \multirow{3}{*}{$\begin{array}{l}\begin{array}{l}\text { frequ } \\
\text { ency }\end{array} \\
104 \\
96\end{array}$} & \multirow{2}{*}{$\begin{array}{l}\text { The } \\
\text { proportion }\end{array}$} & \multicolumn{2}{|c|}{ Characteristics of the } & \multirow{2}{*}{$\begin{array}{l}\text { frequ } \\
\text { ency }\end{array}$} & \multirow{2}{*}{$\begin{array}{l}\text { The } \\
\text { proportio } \\
\text { n } \\
17 \% \\
\end{array}$} \\
\hline gender & men & & & \multirow{4}{*}{$\begin{array}{l}\text { School } \\
\text { type }\end{array}$} & Colleges and universities & & \\
\hline & women & & $48 \%$ & & $\begin{array}{l}\text { Regular institutions of } \\
\text { higher learning }\end{array}$ & 116 & $58 \%$ \\
\hline \multirow{3}{*}{$\begin{array}{l}\text { Age } \\
\text { distributio } \\
\text { n }\end{array}$} & Under the age of 23 & 126 & $63 \%$ & & \multirow[t]{2}{*}{985 or 211 universities } & \multirow[t]{2}{*}{50} & \multirow[t]{2}{*}{$25 \%$} \\
\hline & 23 to 25 & 22 & $11 \%$ & & & & \\
\hline & $\begin{array}{l}25 \text { years of age or } \\
\text { older }\end{array}$ & 52 & $26 \%$ & \multirow{7}{*}{$\begin{array}{l}\text { What } \\
\text { learn } \\
\text { professio } \\
\text { nal }\end{array}$} & Institute of class & 44 & $22 \%$ \\
\hline \multirow{2}{*}{$\begin{array}{l}\text { Is it an } \\
\text { only child }\end{array}$} & Yes & 116 & $58 \%$ & & Although the class & 76 & $38 \%$ \\
\hline & no & 84 & $42 \%$ & & medical & 22 & $11 \%$ \\
\hline \multirow{2}{*}{$\begin{array}{l}\text { Registere } \\
\mathrm{d} \\
\text { residence }\end{array}$} & Cities and towns & 120 & $60 \%$ & & $\begin{array}{l}\text { Agriculture, forestry and } \\
\text { class }\end{array}$ & 6 & $3 \%$ \\
\hline & rural & 80 & $40 \%$ & & The grammar class & 22 & $11 \%$ \\
\hline \multirow{2}{*}{$\begin{array}{l}\text { Students } \\
\text { province }\end{array}$} & Yes & 144 & $72 \%$ & & Normal class & 18 & $9 \%$ \\
\hline & no & 56 & $28 \%$ & & other & 12 & $6 \%$ \\
\hline
\end{tabular}

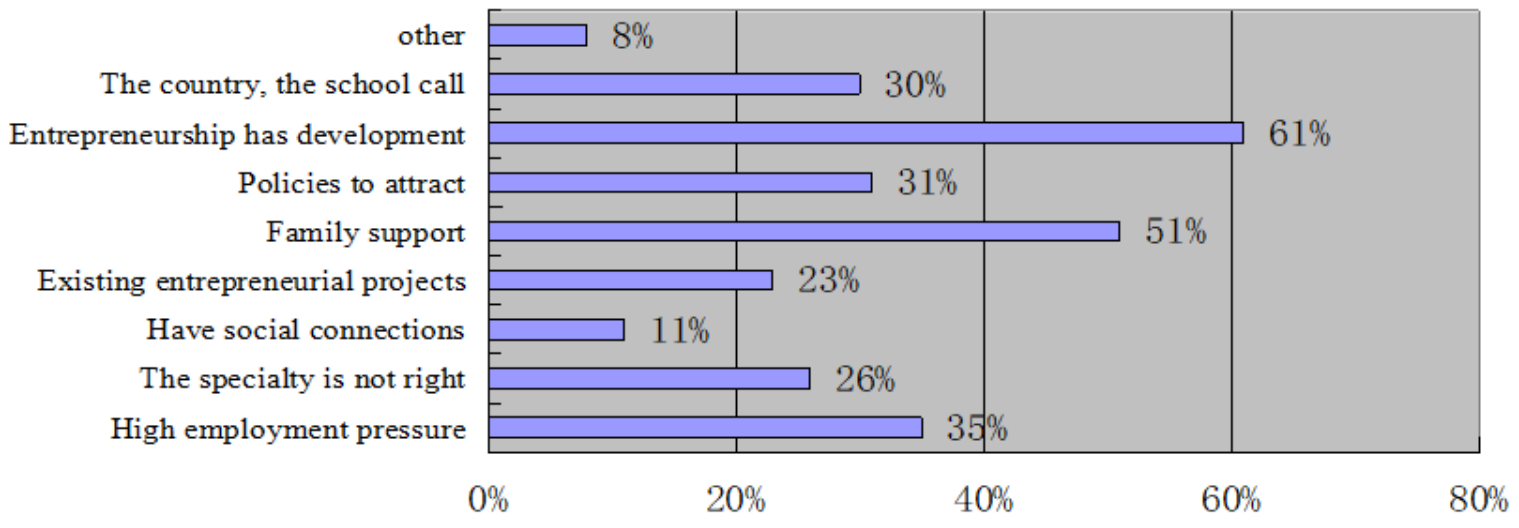

Figure 1. Investigation on the reasons why college graduates choose to start their own businesses

the reasons for the 23 entrepreneurs to start their own businesses are as follows: there is more development space for entrepreneurship (61\%), the support of family members $(51 \%)$, the pressure of employment $(35 \%)$, the attraction of entrepreneurship policies (31\%), and the encouragement and call of the state and schools for entrepreneurship (30\%). Therefore, it can be seen that it is the college graduates' will to start their own businesses. They believe that starting a business can bring more development space and realize personal value, followed by the influence of family and employment pressure. Then, entrepreneurship policies and national encouragement greatly affect entrepreneurs' willingness to start businesses, accounting for more than $30 \%$.

\subsection{College graduates' understanding entrepreneurship support policies}

About the present $\mathrm{S}$ the provincial government issued relevant business policy, be aware of the college graduates, as shown in Figure 2, college graduates for three years tax relief, from administrative charges about preferential tax policies, such as for the government's fiscal interest discount, entrepreneurship training subsidy, talent in popularity generally low of the relevant supporting policies. It can be seen that the promotion of entrepreneurship related policies in S province is still not in place and needs to be further promoted through universities, media and other channels. 


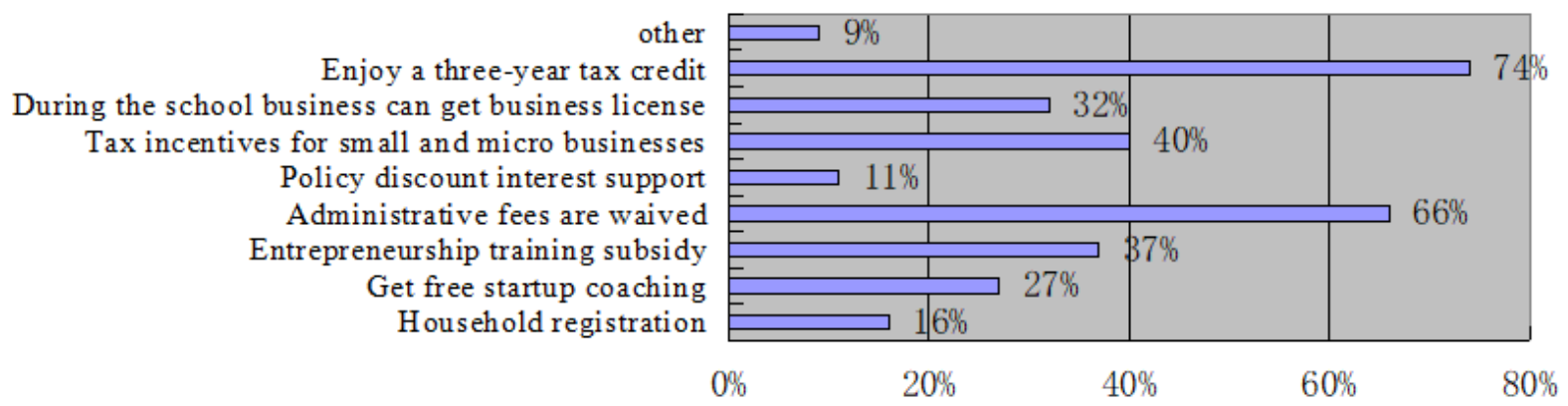

Figure 2. College graduates' understanding of supportive policies for self-employm ent

\subsection{Demand of college graduates for supportive policies for entrepreneurship}

Entrepreneurship policy requirements, the top of the list is the financial loan policy ( $91 \%$ ), followed by tax breaks $(87 \%)$ and business advisory services policy $(85 \%)$, and then in turn is a start-up incubator project $(70 \%)$, entrepreneurial risk aversion policy (60\%), entrepreneurial training subsidy policy $(57 \%)$, other $(45 \%)$. From the policy ranking of these demands, it can be seen that the policies in great demand for college graduates in the early stage of entrepreneurship are, in turn, the support of start-up capital, tax incentives and entrepreneurship consulting services. Therefore, S provincial government can focus on the above three aspects when formulating relevant entrepreneurship policies.

\section{Analysis of entrepreneurship policy effect in $\mathrm{S}$ province}

\subsection{Insufficient publicity}

Compared with developed countries, entrepreneurship of college students in China is still a new thing, and a mature entrepreneurial atmosphere and culture have not yet been formed. Such problems also exist in S province, which has something to do with the insufficient publicity of the government for college graduates to start their own businesses. First of all, there is a lack of cultural atmosphere for college students in $\mathrm{S}$ province to start their own businesses. Traditional Chinese thinking makes students reluctant to start businesses. To change this traditional concept, the government needs to strengthen the propaganda of entrepreneurship. At present, however, there is very little publicity about entrepreneurship. In addition, entrepreneurship education, as the source of entrepreneurship publicity, has not yet played its due role in publicity. Entrepreneurship education should strengthen the cultivation of entrepreneurship from the source.

\subsection{Lack of depth of entrepreneurial support policies}

The breadth and depth of entrepreneurship support policies need to be further expanded and deepened. From the perspective of the depth of entrepreneurial support, first of all, the entrepreneurial support is small, and the policy effect is limited by the actual conditions; Secondly, the object of the existing entrepreneurship support policy has not been subdivided into undergraduate students, higher vocational and higher vocational students, and law students of different majors are not subdivided, and the policy effect is not satisfactory.

\subsection{Low utilization of start-up support funds}

The university students' start-up capital set up by $\mathrm{S}$ provincial government has a low utilization rate every year, which is directly related to the complicated application procedures. For example, small secured loans, due to complex procedures, long cycle, requirements and other reasons, the number of real loans out of a small number, so that entrepreneurs can hardly enjoy the help of small secured loans.

\subsection{The development of venture capital market is not perfec}

The national capital market is relatively perfect, and social capital is the main force of undertaking college students' venture capital. The capital source of college students' venture capital is mostly from the venture capital investment in the capital market. Due to the underdevelopment of capital market in S province, the proportion of social capital participating in college students' venture capital is low, which is not enough to undertake the main task of supporting college students' venture capital. Therefore, it is necessary to cultivate the capital market, set up risk compensation for college students' venture investment, and guide social capital to improve the degree of participation in college students' venture investment. 


\section{Countermeasures to enhance the effect of entrepreneurial support policies in $\mathrm{S}$ province}

\subsection{Clarify the responsibility of the government to support college graduates to start their own businesses}

S provincial government should actively strengthen responsibilities and optimize services, so as to play a key role in the service and support system for college graduates' entrepreneurship. China is in a period of social transformation. Although governments at all levels actively create conditions to encourage college graduates to start their own businesses, compared with developed countries, the institutional environment for promoting college graduates to start their own businesses is not optimized enough, the entrepreneurship policies cannot be well implemented, and the supporting service system is not perfect enough.

\subsection{Improve the current policy support system}

\subsubsection{Optimize the existing self-employment policy for college graduates}

First of all, entrepreneurship supporting policies should be more targeted. The government's policies have played a macro-control and guiding role in the employment of college graduates. Only when the policies formulated by the government are targeted and systematic can they better mobilize the enthusiasm of departments at all levels and complete the service of promoting the entrepreneurship and employment of college graduates.

Secondly, the relevant functional departments should strengthen the implementation of policies. We will improve the implementation of policies, and strengthen the understanding of the employment of college graduates by governments at all levels, talent centers and entrepreneurship and employment departments of colleges and universities.

\subsubsection{Increase financial policy support}

Lack of funds is the most realistic problem college graduates face on the road of entrepreneurship. It is necessary for the state and governments at all levels to provide sufficient financial support for college graduates to start their own businesses. The government needs to change the current restrictions on the start-up capital of college students. The start-up financing policies, including the special financial fund policy, the smallamount guaranteed loan policy and the start-up fund policy, should be more relaxed instead of setting the upper limit of support. Meanwhile, various tax exemptions should cover more industries. The government should provide preferential tax policies for college graduates to start their own businesses and increase tax exemptions for self-employed graduates. The government should also implement the policy of small loans and discount interest, so that graduates can apply for loans in accordance with regulations in the places where they start their own businesses.

\subsubsection{Establish a service system for college graduates to start their own businesses}

The government is not only the manager of university graduates' self-employment, but also the provider of university graduates' self-employment service. The government should focus on the following aspects:

First, we need to establish a policy system for college graduates to start their own businesses, including guiding policies, supportive policies and encouraging policies. Guiding policies include guiding college graduates to start their own businesses, start small and medium-sized micro enterprises, and guide college graduates to start technology-based enterprises. Supportive policies mainly include the introduction of relevant financial preferential policies to help college graduates enter the normal entrepreneurial track as soon as possible; Encouraging policy mainly points out the Taiwan related incentive policy.

Second, the establishment of college graduates entrepreneurship guidance service organization and team system. It is suggested to set up a special institution for college graduates to start their own businesses and to coordinate college students to start their own businesses.

Third, establish a guarantee system for college graduates to start their own businesses. The guarantee system includes organization guarantee, talent guarantee, rights guarantee and fund guarantee. The government should make efforts in these areas to better provide escort services for college graduates to start their own businesses.

Fourth, it is necessary to establish the public opinion propaganda system, supervision and management system and entrepreneurship market system for college graduates.

\section{Conclusion}

Based on the questionnaire survey and the understanding of the influencing factors of college students' entrepreneurship, this paper analyzes college students' understanding of entrepreneurship support policies and their demand for policies. The study found that more than 80 percent of respondents said they most needed government financial loans, tax breaks and counseling when starting a business. However, the existing supporting policies in S province are not well publicized and the supporting contents are not targeted, leading to the low utilization rate of the policies and the insignificant effect. Therefore, this paper suggests that the government should clarify the responsibility of support and division of labor at all levels, optimize the support system, improve the support of financial policies, and make due contributions to promoting the entrepreneurship of college students in this region. 


\section{References}

1. Chen xiao, Research on factors of success of college students' innovative entrepreneurship, vol. 12. Higher education and economics, 2011, pp.42-45.

2. Zhaoxin Huang, Erlei Zeng, Cooperation in American entrepreneurship education: concept, model and enlightenment, vol. 31. Higher education research, 2010, pp.105-109.

3. Fengcheng Wang, lili Bai, Research on countermeasures to optimize the entrepreneurial environment of college students, vol. 6. Statistics and management, 2015, pp.126-127.

4. Yu Wang, Study on the influencing factors of college students' entrepreneurial intention, vol. 3 . Economics and management, 2018, pp.64-68.

5. Yinghua Ye, The dilemma and transformation of college students' entrepreneurship policy,vol. 1. Educational development research, 2011, pp.34-39.

6. Xiong Wei, The construction framework and implementation mode of college students' entrepreneurship policy system, vol. 25. Journal of shaanxi institute of education, 2009, pp.28-31. 